\title{
Bilateral adrenal incidentalomas differ from unilateral adrenal incidentalomas in subclinical cortisol hypersecretion but not in potential clinical implications
}

\author{
Evangeline Vassilatou, Andromachi Vryonidou' ${ }^{1}$, Dimitrios loannidis ${ }^{2}$, \\ Stavroula A Paschou', Maria Panagou ${ }^{2}$ and loanna Tzavara ${ }^{2}$
}

Endocrine Unit, 2nd Department of Internal Medicine - Propaedeutic, 'Attikon' University Hospital, 1 Rimini Street, Haidari, Athens 12462, Greece, 'Department of Endocrinology, Diabetes and Metabolism, 'Red Cross Hospital', Athens, Greece and ${ }^{2}$ Department of Endocrinology, Diabetes and Metabolism, 'Amalia Fleming' General Hospital, Athens, Greece

\author{
Correspondence \\ should be addressed \\ to E Vassilatou \\ Email \\ niadas@hol.gr
}

\begin{abstract}
Objective: To investigate the possibility of a different prevalence of subclinical Cushing's syndrome (SCS) and potentially related morbidities between patients with unilateral adrenal incidentalomas (UAI) and bilateral adrenal incidentalomas (BAI), as existing data are few and controversial.
\end{abstract}

Design: Prospective observational study.

Methods: Clinical examination, biochemical tests, and hormonal evaluation were performed in 298 consecutive patients with adrenal incidentalomas, unilateral in 224 patients (75.2\%), bilateral in 74 patients (24.8\%), with apparently benign masses based on imaging characteristics and after exclusion of overt endocrine disease. The diagnosis of SCS was based on a post-dexamethasone suppression test ( $2 \mathrm{mg}$ dexamethasone/24 $\mathrm{h}$ for $48 \mathrm{~h}$ ), with serum cortisol level $\geq 1.8 \mu \mathrm{g} / \mathrm{dl}$ combined with at least one abnormal result of the other hormonal measurements.

Results: SCS was diagnosed in 66 out of 298 (22.1\%) patients, being more frequent in patients with BAI (35.1 vs $17.9 \%$, $P=0.003$, for BAI and UAI respectively). Hypertension, type 2 diabetes mellitus, impaired glucose tolerance, and dyslipidemia were of a similar frequency in both groups. SCS patients with UAI and BAI did not differ in age, gender, $\mathrm{BMI}$, waist circumference, and mass size. Factors related to SCS were the presence of $\mathrm{BAI}(\mathrm{OR}, 3.24 ; 95 \% \mathrm{Cl}, 2.31-4.54)$ and mass size (OR, 2.63; $95 \% \mathrm{Cl}, 1.31-5.26)$.

Conclusion: BAI patients present more often with SCS when compared with UAI patients; however, morbidities potentially related to subtle cortisol hypersecretion were of a similar frequency in both groups. Further studies are needed to clarify whether this difference in hormonal activity may be related to different pathophysiologies.

\section{Introduction}

Incidentally discovered adrenal masses, initially reported in autopsy series, have become an increasingly common clinical problem due to the widespread use and advanced technology of imaging evaluation performed for reasons unrelated to adrenal disease (1). The prevalence of adrenal incidentalomas (AIs) in the general population varies between 1.4 and $8.7 \%$ in most autopsy series, depending on the used methodology (1) and between 0.4 and 5.0\% in clinical series, depending on patient inclusion criteria $(2,3,4)$. The prevalence is increasing with age, as shown in autopsy and clinical series with a peak in the eighth decade of life $(1,5)$. There are no significant sex differences
(C) 2014 European Society of Endocrinology Printed in Great Britain
Published by Bioscientifica Ltd. 
as shown in autopsy series, although an increased prevalence in women is reported in clinical series, attributed to referral bias $(1,5)$.

Given that the definition of adrenal incidentaloma excludes patients undergoing imaging evaluation as part of staging procedure for malignancy, the vast majority of these lesions are benign non-hypersecreting cortical neoplasms. However, a significant percentage of cases present with subclinical hormonal activity, mainly concerning glucocorticoid secretion. Subclinical autonomous cortisol hypersecretion is characterized by subtle alterations of the hypothalamic-pituitary-adrenal axis due to adrenal autonomy in the absence of typical clinical phenotype of hypercortisolism, a disorder that has also been described as subclinical Cushing's syndrome (SCS) (6). The prevalence of SCS in patients with AIs varies between 5 and 24\% in most studies depending on the used biochemical diagnostic criteria $(7,8,9,10)$, as till now there is no consensus for the diagnostic approach. An increased prevalence of hypertension, diabetes, obesity, osteoporosis, and dyslipidemia has been found in patients with clinically silent AIs, either with normal adrenal function or with SCS $(1,5,6,7,8,9,10,11)$, being even higher in patients with SCS, potentially associated with subtle cortisol hypersecretion $(6,7,8,11,12)$.

Bilateral adrenal incidentalomas (BAI) are reported in $7.8-15 \%$ of all patients $(4,9,11,12)$, a much higher prevalence than expected from the estimated occurrence of $0.09-1.11 \%$ for the coincidence of a single adenoma in both adrenals (13). Most of these lesions are benign, nonfunctioning cortical neoplasms. Although the etiology and pathogenesis of sporadic adrenal tumors are under research, there are few data suggesting possible pathogenetic differences between unilateral adrenal incidentalomas (UAI) and BAI $(13,14)$. Recently, the possibility of a different prevalence in SCS and in clinical characteristics between patients with UAI and BAI has been examined; however, existing data are limited and controversial $(15,16,17,18)$.

In this prospective study, we investigated subclinical cortisol hypersecretion and possible clinical implications in patients with UAI and BAI, with benign imaging characteristics and without overt hyperfunction, aiming to detect possible differences between the two subsets of patients.

\section{Subjects and methods}

\section{Patients}

Patients with newly diagnosed AIs with a diameter $\geq 1 \mathrm{~cm}$ by CT were evaluated in two centers ('Amalia Fleming'
General Hospital and 'Red Cross Hospital') from January 2002 to December 2012. None of the patients were on a staging procedure for malignancy or diagnostic investigation for hypertension.

Inclusion criteria were: i) absence of symptoms and signs of overt Cushing's syndrome; ii) absence of conditions related to lack of dexamethasone suppression (depression, alcoholism, renal and hepatic failure, and acute illnesses); iii) no use of medications related to altered dexamethasone or cortisol metabolism; iv) apparently benign incidentalomas on the basis of their CT characteristics, indicating the presence of adrenal adenomas (homogeneous, hypodense masses with an attenuation value of ten Hounsfield Units or less on thin-section unenhanced CT and well-defined margins) - incidentalomas with imaging characteristics of myelolipomas, hemorrhage, and adrenal cysts were excluded; and v) hormonal evaluation excluding congenital adrenal hyperplasia (normal levels of serum 17-hydroxyprogesterone), primary hyperaldosteronism (normal serum aldosterone levels with normal plasma renin activity and normal aldosterone:plasma renin activity ratio), and pheochromocytoma (normal 24-h urinary vanillyl mandelic acid (VMA) and metanephrines).

None of the patients with bilateral incidentalomas had the typical imaging characteristics of adrenocorticotropic hormone (ACTH)-independent macronodular hyperplasia (massively enlarged adrenals with macronodules).

\section{Study protocol}

All patients were hospitalized. They underwent clinical examination, routine biochemical tests, and hormonal evaluation. At clinical examination, anthropometric measurements (weight, height, and waist and hip circumference) and blood pressure were recorded. Hormonal evaluation comprised: i) baseline assessment with serum (or plasma) cortisol at 0800 and $2400 \mathrm{~h}$, morning plasma ACTH and serum DHEA-S, and 24-h urinary free cortisol and ii) a low-dose dexamethasone suppression test (LDDST: dexamethasone $0.5 \mathrm{mg}$ orally, every $6 \mathrm{~h}$ for $48 \mathrm{~h}$ ). Non-diabetic patients underwent a 2 -h oral glucose tolerance test with $75 \mathrm{~g}$ glucose during which glucose levels were measured hourly.

Premenopausal women were studied in the follicular phase of the cycle.

The diagnosis of SCS was based on a post-LDDST (at 08:00, $8 \mathrm{~h}$ after the last dose of dexamethasone) with serum (or plasma) cortisol level $\geq 1.8 \mu \mathrm{g} / \mathrm{dl}$ ( $\geq 50 \mathrm{nmol} / \mathrm{l}$ ) combined with at least one abnormal result of the 
other hormonal measurements: i) midnight serum (or plasma) cortisol $>7.5 \mu \mathrm{g} / \mathrm{dl}(>208 \mathrm{nmol} / \mathrm{l})$; ii) morning plasma ACTH $<9.0 \mathrm{pg} / \mathrm{ml}$ ( $<2.0 \mathrm{pmol} / \mathrm{l})$; iii) low-for-age serum DHEA-S; and iv) 24-h urinary free cortisol (UFC) $>90 \mu \mathrm{g}(>250 \mathrm{nmol})$, in the absence of clinical signs of cortisol excess.

Patients with a BMI $\geq 30 \mathrm{~kg} / \mathrm{m}^{2}$ were defined as obese (19). Patients with known hypertension receiving antihypertensive treatment and patients with systolic arterial blood pressure of $140 \mathrm{mmHg}$ or more and/or diastolic pressure of $90 \mathrm{mmHg}$ or more were defined as hypertensive (20). Patients with known type 2 diabetes mellitus receiving antidiabetic treatment and patients with a fasting serum glucose level $\geq 126 \mathrm{mg} / \mathrm{dl}(\geq 7.0 \mathrm{mmol} / \mathrm{l})$ and/or a serum glucose level $\geq 200 \mathrm{mg} / \mathrm{dl}(\geq 11.1 \mathrm{mmol} / \mathrm{l})$ at $2 \mathrm{~h}$ after glucose load were defined as diabetics (21). Patients with a serum glucose level of 140-199 mg/dl (7.8-11.05 mmol/l) at $2 \mathrm{~h}$ after glucose challenge were defined as having impaired glucose tolerance (IGT)(21). Patients with known dyslipidemia receiving hypolipidemic treatment and patients with fasting serum triglyceride levels $>150 \mathrm{mg} / \mathrm{dl}(>1.7 \mathrm{mmol} / \mathrm{l})$ and/or serum total cholesterol levels $>200 \mathrm{mg} / \mathrm{dl}(>5.17 \mathrm{mmol} / \mathrm{l})$, in combination with LDL cholesterol $>150 \mathrm{mg} / \mathrm{dl}(>3.88 \mathrm{mmol} / \mathrm{l})$ or $\mathrm{HDL}$ cholesterol $<40 \mathrm{mg} / \mathrm{dl}(<1.04 \mathrm{mmol} / \mathrm{l})$ in men and $<50 \mathrm{mg} / \mathrm{dl}(<1.29 \mathrm{mmol} / \mathrm{l})$ in women, were defined as dyslipidemics (22).

The study protocol was approved by the ethics committee of both hospitals and informed consent was obtained from all patients.

\section{Assays}

Hormone measurements were performed with commercially available kits.

Cortisol was measured in plasma from 2002 to 2009 and in serum since 2009 with the same electrochemiluminescence immunoassay (Elecsys/Cobas, Roche diagnostics $\mathrm{GmbH}$ ) with a reported functional sensitivity of $2.0 \mathrm{nmol} / 1$, lower detection limit of $0.5 \mathrm{nmol} / 1$, and intraand inter-assay coefficient of variation $(\mathrm{CV})$ values of 1.3 and $1.6 \%$ respectively. Urinary free cortisol was measured after dichloromethane extraction with the same assay. Plasma ACTH was measured by the immunoradiometric method using two assays: from 2002 to 2007 (Nichols Institute Diagnostics, San Juan Capistrano, CA, USA) with a lower detection limit of $0.22 \mathrm{pmol} / 1$ and intraand inter-assay CV values of 5 and 6\% respectively and, since 2007 (BRAHMS Diagnostica GmbH, Berlin, Germany) with a functional sensitivity of $2.4 \mathrm{pmol} / \mathrm{l}$ and intra- and inter-assay CV values of 4.2 and $7.4 \%$ respectively. Serum DHEA-S was measured by the RIA using three assays: from 2002 to 2007 (Nichols Institute Diagnostics) from 2007 to 2009 (Biosource Europe SA, Nivelles, Belgium) and since 2009 (Coat-A-Count, Siemens Healthcare Diagnostics, Los Angeles, CA, USA) with a sensitivity of $1.1 \mu \mathrm{g} / \mathrm{dl}$ and intra- and inter-assay $\mathrm{CV}$ values of 4.6 and $8.2 \%$ respectively.

Hematological profile, lipid profile, glucose, creatinine, and liver function tests were determined by routine laboratory methods.

\section{Statistical analysis}

Results for continuous variables are expressed as mean \pm s.D. and for categorical variables as absolute numbers or percentages. Differences in continuous variables between groups were tested using the unpaired $t$-test or the MannWhitney $U$ test, as appropriate. Differences in categorical variables between groups were tested using the $\chi^{2}$-test with the Yates Correction or Fisher's exact test, as appropriate. Pearson's correlation was used to explore the association between pairs of continuous variables. Univariate logistic regression analysis was applied to evaluate variables (presence of bilateral incidentalomas and size of the largest lesion) as predictors of the risk for subclinical hypercortisolism in the whole cohort. All statistical analyses were performed using the Statistical Package for Social Sciences (SPSS 16.0, Inc.). A $P$ value of $<0.05$ was considered statistically significant.

\section{Results}

A total of 298 consecutive eligible patients with adrenal masses (maximal diameter 1.0-6.8 cm) participated in the study: 91 men and 207 women (49 premenopausal), aged $60 \pm 12$ years, and with a BMI of $30.2 \pm 5.6 \mathrm{~kg} / \mathrm{m}^{2}$. Unilateral incidentalomas were encountered in 224 patients $(75.2 \%)$ and bilateral in 74 patients $(24.8 \%)$. Three patients with unilateral incidentalomas had two masses on the same adrenal. In these patients and in patients with bilateral incidentalomas, a maximal diameter of the largest mass is reported.

\section{Patients with bilateral and unilateral incidentalomas}

Patients with BAI $(n=74)$ did not differ in clinical characteristics (age, gender, BMI, and waist circumference) and mass size (the maximal diameter of the largest mass) from patients with UAI $(n=224)(2.6 \pm 1.0$ vs 
$2.4 \pm 1.1 \mathrm{~cm}, P>0.05)$. There was a trend for an increased frequency of hypertension in patients with BAI $(P=0.058)$, while type 2 diabetes mellitus, IGT, and dyslipidemia were of a similar frequency in both groups (Table 1). Hormonal evaluation showed that patients with BAI had significantly higher post-LDDST cortisol levels $(2.1 \pm 1.8$ vs $1.55 \pm 1.54 \mu \mathrm{g} / \mathrm{dl}, \quad P=0.014$ ), higher UFC levels ( $66.4 \pm 36.9$ vs $51.9 \pm 30.6 \mu \mathrm{g} / 24 \mathrm{~h}, P=0.003$ ), and lower ACTH levels $(16.5 \pm 9.4$ vs $19.9 \pm 10.2 \mathrm{pg} / \mathrm{ml}, P=0.013)$ than patients with UAI, while midnight serum cortisol and DHEA-S levels were similar in both groups (Table 1). In both groups of patients, the mass diameter was positively related to post-LDDST cortisol levels $(r=0.594$, $P<0.001$ and $r=0.376, P<0.001$ for BAI and UAI respectively) and negatively related to ACTH $(r=-0.382$, $P=0.001$ and $r=-0.309, P<0.001$ ).

Table 1 Clinical and laboratory characteristics of patients with unilateral (UAI) and bilateral adrenal incidentalomas (BAI). Results for continuous variables are expressed as mean \pm s.D. and median, range (minimum-maximum), in italics. Results for binary variables are expressed as absolute numbers and percentage in parentheses. $P<0.05$ is considered statistically significant for the unpaired $t$-test or the Mann-Whitney $U$-test (continuous variables) and the Pearson $\chi^{2}$-test or Fisher's exact test (binary variables).

\begin{tabular}{|c|c|c|c|}
\hline Variable & UAI $(n=224)$ & BAI $(n=74)$ & $P$ value \\
\hline Age (years) & $\begin{array}{c}60.4 \pm 12.4 \\
62,28-87\end{array}$ & $\begin{array}{c}59.0 \pm 11.0 \\
59,32-83\end{array}$ & 0.403 \\
\hline Gender M/F (\%) & 69/155 (69.2) & $22 / 52(70.3)$ & 0.977 \\
\hline BMI $\left(\mathrm{kg} / \mathrm{m}^{2}\right)$ & $\begin{array}{c}30.0 \pm 5.7 \\
29,18.4-57\end{array}$ & $\begin{array}{c}30.5 \pm 5.4 \\
29.6,22.1-47.2\end{array}$ & 0.519 \\
\hline $\begin{array}{l}\text { Waist circum- } \\
\text { ference }(\mathrm{cm})\end{array}$ & $\begin{array}{c}96.1 \pm 12.9 \\
93.5,72-136\end{array}$ & $\begin{array}{l}98.6 \pm 13.0 \\
96,75-138\end{array}$ & 0.205 \\
\hline Mass size $(\mathrm{cm})$ & $\begin{array}{l}2.4 \pm 1.1 \\
2.1,1-6.8\end{array}$ & $\begin{array}{l}2.6 \pm 1.0 \\
2.5,1-4.7\end{array}$ & 0.266 \\
\hline Hypertension (\%) & $134(59.8)$ & $54(73)$ & 0.058 \\
\hline Type 2 DM (\%) & $45(20.1)$ & $21(28.4)$ & 0.184 \\
\hline IGT (\%) & $6(2.7)$ & $2(2$ & 0.715 \\
\hline Dyslip & $146(65.2)$ & $54(73.0)$ & 0.274 \\
\hline $\begin{array}{l}\text { Post-LDDST F } \\
(\mu \mathrm{g} / \mathrm{dl})\end{array}$ & $\begin{array}{c}1.55 \pm 1.54 \\
1.13,0.3-15\end{array}$ & $\begin{array}{c}2.14 \pm 1.82 \\
1.44,0.3-7.6\end{array}$ & 0.014 \\
\hline $\begin{array}{l}\text { Midnight cortisol } \\
(\mu \mathrm{g} / \mathrm{dl})\end{array}$ & $\begin{array}{c}4.27 \pm 2.5 \\
3.68,0.5-14.53\end{array}$ & $\begin{array}{c}4.79 \pm 2.77 \\
4.1,0.87-11.3\end{array}$ & 0.247 \\
\hline ACTH $(p g / m l)$ & $\begin{array}{l}19.9 \pm 10.2 \\
18,2-55.5\end{array}$ & $\begin{array}{c}16.5 \pm 9.4 \\
16.5,2-41\end{array}$ & 0.013 \\
\hline DHEA-S $(\mu \mathrm{g} / \mathrm{dl})$ & $\begin{array}{c}83.1 \pm 60.6 \\
65.0,11.5-303\end{array}$ & $\begin{array}{c}80.6 \pm 60.6 \\
64.8,13.7-344\end{array}$ & 0.755 \\
\hline UFC $(\mu \mathrm{g} / 24 \mathrm{~h})$ & $\begin{array}{c}51.9 \pm 30.6 \\
44.4,13.3-167.6\end{array}$ & $\begin{array}{c}66.4 \pm 36.7 \\
60.9,15.6-183\end{array}$ & 0.003 \\
\hline SCS (\%) & $40(17.9)$ & $26(35.1)$ & 0.003 \\
\hline
\end{tabular}

IGT, impaired glucose tolerance; LDDST, low-dose dexamethasone suppression test; SCS, subclinical Cushing's syndrome.
SCS was diagnosed in 66 out of 298 (22.1\%) patients (Table 2). All patients had above cut-off post-LDDST cortisol levels, being a prerequisite for the diagnosis, 30 out of $66(45.5 \%)$ patients had below cut-off ACTH levels, 25 out of $62(40.3 \%)$ patients had above cut-off midnight serum cortisol levels, 12 out of $66(18.2 \%)$ patients had low DHEA-S levels, and 11 out of 60 (18.3\%) patients had high UFC levels (Fig. 1). A significantly greater number of bilateral incidentaloma patients were diagnosed with SCS compared with unilateral incidentaloma patients $(26 / 74,35.1$ vs $40 / 224,17.9 \%$, $P=0.003)$ (Table 1).

\section{Patients with and without SCS}

Patients with SCS did not differ in clinical characteristics and the frequency of hypertension, type 2 diabetes mellitus, and IGT from patients with normal adrenal function, but they had larger adrenal masses $(3.4 \pm 0.8$ vs $2.2 \pm 1.0 \mathrm{~cm}, P<0.001)$, an increased frequency of dyslipidemia $(P=0.032)$, lower plasma ACTH $(9.6 \pm 5.8$ vs $21.7 \pm 9.5 \mathrm{pg} / \mathrm{ml}, P<0.001)$ and DHEA-S levels $(495 \pm 297$ vs $926 \pm 626 \mu \mathrm{g} / \mathrm{dl}, P<0.001)$, and higher UFC $(66.3 \pm 33.3$ vs $52.3 \pm 31.8 \mu \mathrm{g} / 24 \mathrm{~h}, P=0.004)$ and midnight serum cortisol levels ( $6 \pm 2.5$ vs $3.9 \pm 2.4, P<0.001)$, in addition to post-LDDST cortisol levels, which differed by definition between subgroups (Table 2).

Subgroup analysis - SCS patients with bilateral and unilateral incidentalomas

SCS patients with BAI $(n=26)$ did not differ in clinical characteristics, mass size (the maximal diameter of the largest mass), and hormonal evaluation from SCS patients with UAI $(n=40)$ (Table 2). There was a trend for an increased frequency of type 2 diabetes mellitus in SCS patients with BAI $(P=0.054)$, while hypertension, IGT, and dyslipidemia were of a similar frequency in both SCS subgroups (Table 3).

UAI patients with and without SCS $\bullet$ Patients with UAI and SCS $(n=40)$ did not differ in clinical characteristics but had larger adrenal masses than patients with unilateral incidentalomas and normal adrenal function $(n=184)$ $(3.4 \pm 0.9$ vs $2.2 \pm 1.0 \mathrm{~cm}, P<0.001$ respectively). Except for post-LDDST cortisol levels, which differed by definition between subgroups, patients with and without SCS had lower ACTH $(10.1 \pm 5.6$ vs $22.0 \pm 9.8 \mathrm{pg} / \mathrm{ml}, P<0.001)$ and DHEA-S levels $(47.3 \pm 32.8$ vs $91.2 \pm 61.0 \mu \mathrm{g} / \mathrm{dl}, P<0.001)$, and higher UFC $(62.7 \pm 30.7$ vs $50.2 \pm 30.5 \mu \mathrm{g} / 24 \mathrm{~h}$, $P<0.05)$ and midnight serum cortisol levels $(6.2 \pm 2.46$ 
Table 2 Clinical characteristics of adrenal incidentaloma patients with and without subclinical Cushing's syndrome. Results for continuous variables are expressed as mean \pm s.D. and median, range (minimum-maximum), in italics. Results for binary variables are expressed as absolute numbers and percentage in parentheses. $P<0.05$ is considered statistically significant for the unpaired $t$-test or the Mann-Whitney $U$-test (continuous variables) and the Pearson $\chi^{2}$-test or Fisher's exact test (binary variables).

\begin{tabular}{|c|c|c|c|}
\hline Variable & $\mathbf{N F}(n=232)$ & SCS $(n=66)$ & $P$ value \\
\hline Age (years) & $\begin{array}{c}59.6 \pm 12.3 \\
60,28-87\end{array}$ & $\begin{array}{l}61.7 \pm 11.0 \\
62.5,32-82\end{array}$ & 0.198 \\
\hline Gender M/F (\%) & $77 / 155$ (66.8) & $14 / 52$ (78.9) & 0.086 \\
\hline BMI $\left(\mathrm{kg} / \mathrm{m}^{2}\right)$ & $\begin{array}{c}30.1 \pm 5.8 \\
29,18.4-57\end{array}$ & $\begin{array}{c}30.4 \pm 5.0 \\
29,22.1-48.9\end{array}$ & 0.652 \\
\hline $\begin{array}{l}\text { Waist circum- } \\
\text { ference }(\mathrm{cm})\end{array}$ & $\begin{array}{l}96.6 \pm 13.3 \\
94,72-138\end{array}$ & $\begin{array}{l}97.2 \pm 12.1 \\
96,75-136\end{array}$ & 0.759 \\
\hline Mass size $(\mathrm{cm})$ & $\begin{array}{l}2.2 \pm 1.0 \\
2.1,1-6.8\end{array}$ & $\begin{array}{c}3.4 \pm 0.8 \\
3.25,1.6-5.7\end{array}$ & $<0.001$ \\
\hline Hypertension (\%) & $141(60.8)$ & 47 (71.2) & 0.160 \\
\hline Type 2 DM (\%) & $48(20.7)$ & $18(27.3)$ & 0.333 \\
\hline IGT (\%) & $6(2.6)$ & $2(3.0)$ & $>0.999$ \\
\hline Dyslipidemia (\%) & $148(63.8)$ & $52(78.8)$ & 0.032 \\
\hline $\begin{array}{l}\text { Post-LDDST F } \\
(\mu \mathrm{g} / \mathrm{dl})\end{array}$ & $\begin{array}{l}1.04 \pm 0.55 \\
0.95,0.3-4\end{array}$ & $\begin{array}{r}4.0 \pm 2.04 \\
3.4,2-15\end{array}$ & $<0.001$ \\
\hline $\begin{array}{l}\text { Midnight cortisol } \\
(\mu \mathrm{g} / \mathrm{dl})\end{array}$ & $\begin{array}{c}3.9 \pm 2.38 \\
3.2,0.5-14.53\end{array}$ & $\begin{array}{c}6 \pm 2.52 \\
6.5,2.2-11.7\end{array}$ & $<0.001$ \\
\hline ACTH $(\mathrm{pg} / \mathrm{ml})$ & $\begin{array}{l}21.7 \pm 9.5 \\
20,2-55.5\end{array}$ & $\begin{array}{c}9.6 \pm 5.8 \\
8.95,2-28.6\end{array}$ & $<0.001$ \\
\hline DHEA-S ( $\mu \mathrm{g} / \mathrm{dl})$ & $\begin{array}{c}92.6 \pm 62.6 \\
72,11.5-344\end{array}$ & $\begin{array}{c}49.5 \pm 29.7 \\
44.7,13.7-199\end{array}$ & $<0.001$ \\
\hline UFC ( $\mu \mathrm{g} / 24 \mathrm{~h})$ & $\begin{array}{c}52.3 \pm 31.8 \\
45.4,13.3-167.6\end{array}$ & $\begin{array}{c}66.3 \pm 33.3 \\
61.3,15-183\end{array}$ & 0.004 \\
\hline
\end{tabular}

NF, normal adrenal function; SCS, subclinical Cushing's syndrome; IGT, impaired glucose tolerance; LDDST, low-dose dexamethasone suppression test.

vs $3.8 \pm 2.28 \mu \mathrm{g} / \mathrm{dl}, P<0.001)$ than patients with unilateral incidentalomas and normal adrenal function. Hypertension, type 2 diabetes mellitus, IGT, and dyslipidemia were of a similar frequency in both subgroups (Table 3).

BAI patients with and without SCS $~$ Patients with BAI and SCS $(n=26)$ did not differ in clinical characteristics but had larger adrenal masses (the maximal diameter of the largest mass) than patients with bilateral incidentalomas and normal adrenal function $(n=48)(3.4 \pm 0.7$ vs $2.1 \pm 0.8 \mathrm{~cm}, P<0.001$ respectively). Except for postLDDST cortisol levels, which differed by definition between subgroups, patients with BAI and SCS had lower ACTH $(8.9 \pm 6.1$ vs $20.6 \pm 8.3 \mathrm{pg} / \mathrm{ml}, P<0.001)$ and DHEA-S levels $(52.7 \pm 24.5$ vs $96.7 \pm 69.0 \mu \mathrm{g} / \mathrm{dl}, P<0.001)$, and higher midnight serum cortisol levels $(5.8 \pm 2.65$ vs
$4.26 \pm 2.7 \mu \mathrm{g} / \mathrm{dl}, P<0.05)$ than patients with bilateral incidentalomas and normal adrenal function. Hypertension, type 2 diabetes mellitus, IGT, and dyslipidemia were of a similar frequency in both subgroups (Table 3).

Logistic regression analysis $>$ Univariate regression analysis showed that the probability of SCS correlated positively with the mass size and the presence of BAI, findings that persisted after multivariate adjustment for age, BMI, and waist circumference. In addition, univariate regression analysis showed that the presence of bilateral incidentalomas was not related to dyslipidemia, hypertension, and type 2 diabetes mellitus.

\section{Discussion}

In this prospective study, 224 patients with UAI and 74 patients with BAI without overt endocrine disease, presumed to be adrenal cortical adenomas, were evaluated for the presence of subclinical cortisol hypersecretion and potential clinical implications, to investigate any existing differences. A significantly higher prevalence of SCS was detected in patients with BAI, whereas the frequency of obesity and central adiposity as well as morbidities that could be considered as adverse effects of subtle cortisol hypersecretion did not differ between SCS patients with BAI and UAI. Moreover, the probability for SCS in the whole cohort correlated positively with the mass size and the presence of BAI.

The possibility of a difference in subtle cortisol hypersecretion and potentially related morbidities

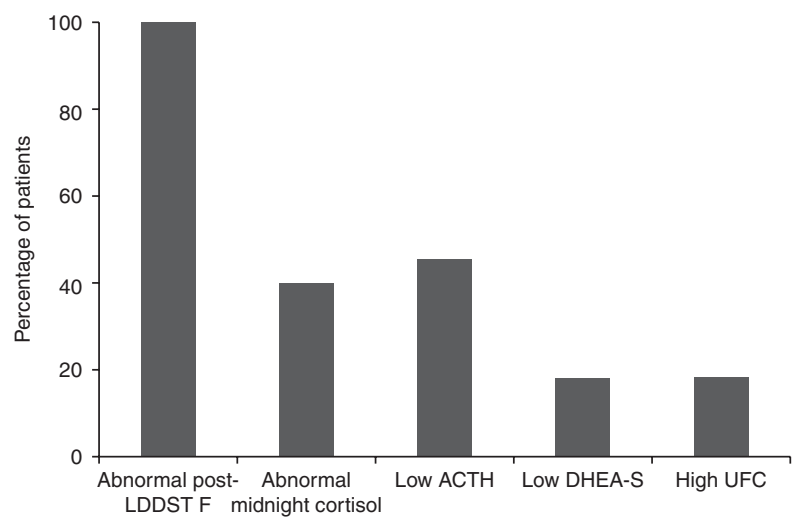

Figure 1

Percentage of SCS patients with positive tests according to the used diagnostic criteria. 
Table 3 Clinical and laboratory characteristics of patients with unilateral (UAI) and bilateral adrenal incidentalomas (BAI) with and without subclinical Cushing's syndrome. Results for continuous variables are expressed as mean \pm s.D. and median, range (minimummaximum), in italics. Results for binary variables are expressed as absolute numbers and percentage in parentheses. $P<0.05$ is considered statistically significant for the unpaired $t$-test or the Mann-Whitney $U$-test (continuous variables) and the Pearson $\chi^{2}$-test or Fisher's exact test (binary variables).

\begin{tabular}{|c|c|c|c|c|}
\hline \multirow[b]{2}{*}{ Variable } & \multicolumn{2}{|c|}{ UAI $(n=224)$} & \multicolumn{2}{|c|}{ BAI $(n=74)$} \\
\hline & $\operatorname{SCS}(n=40)$ & NF $(n=184)$ & $\operatorname{SCS}(n=26)$ & NF $(n=48)$ \\
\hline Age (years) & $\begin{array}{l}63.0 \pm 11.6 \\
65.5,39-82\end{array}$ & $\begin{array}{l}59.8 \pm 12.5 \\
61.5,28-87\end{array}$ & $\begin{array}{l}59.7 \pm 9.9 \\
60,32-74\end{array}$ & $\begin{array}{l}58.7 \pm 11.6 \\
56.5,36-83\end{array}$ \\
\hline Gender M/F (\%) & 9/31 (77.5) & $60 / 124(67.4)$ & $5 / 21(80.8)$ & $17 / 31(64.6)$ \\
\hline BMI $\left(\mathrm{kg} / \mathrm{m}^{2}\right)$ & $\begin{array}{c}30.5 \pm 4.9 \\
29.5,24-48.9\end{array}$ & $\begin{array}{c}29.9 \pm 5.6 \\
29,18.4-57\end{array}$ & $\begin{array}{c}30.4 \pm 5.2 \\
28.9,22.1-40\end{array}$ & $\begin{array}{c}30.6 \pm 5.6 \\
30.2,23-47.2\end{array}$ \\
\hline WC $(\mathrm{cm})$ & $\begin{array}{l}97.0 \pm 13.5 \\
95,77-136\end{array}$ & $\begin{array}{l}95.9 \pm 12.8 \\
93,72-128\end{array}$ & $\begin{array}{l}97.5 \pm 9.6 \\
96,75-120\end{array}$ & $\begin{array}{c}99.2 \pm 14.7 \\
96.5,78-138\end{array}$ \\
\hline Mass size $(\mathrm{cm})$ & $\begin{array}{c}3.4 \pm 0.9^{a} \\
3.4,1.6-5.7\end{array}$ & $\begin{array}{l}2.2 \pm 1.0 \\
2.1,1-6.8\end{array}$ & $\begin{array}{c}3.4 \pm 0.7^{b} \\
3.15,2.5-4.7\end{array}$ & $\begin{array}{l}2.1 \pm 0.8 \\
2.1,1-4.1\end{array}$ \\
\hline Hypertension (\%) & 27 (67.5) & $107(58.2)$ & $20(76.9)$ & $34(70.8)$ \\
\hline $\begin{array}{l}\text { Type } 2 \text { DM (\%) } \\
\text { IGT (\%) }\end{array}$ & $\begin{array}{c}7(17.5) \\
1(2.5)\end{array}$ & $\begin{array}{c}38(20.7) \\
5(2.7)\end{array}$ & $\begin{array}{c}11(42.3) \\
1(3.8)\end{array}$ & $\begin{array}{c}10(20.8) \\
1(2.1)\end{array}$ \\
\hline Dyslipidemia (\%) & $30(75.0)$ & $116(63.0)$ & $22(84.6)$ & $32(66.7)$ \\
\hline LDDST F ( $\mu \mathrm{g} / \mathrm{dl})$ & $\begin{array}{l}3.8 \pm 2.3^{a} \\
3.05,2-15\end{array}$ & $\begin{array}{c}1.0 \pm 0.6 \\
0.98,0.3-4\end{array}$ & $\begin{array}{c}4.2 \pm 1.5^{b} \\
3.95,2.3-7.6\end{array}$ & $\begin{array}{c}1.0 \pm 0.4 \\
0.91,0.3-1.8\end{array}$ \\
\hline Midnight cortisol ( $\mu \mathrm{g} / \mathrm{dl})$ & $\begin{array}{c}6.2 \pm 2.46^{\mathrm{a}} \\
5.58,2.2-11.78\end{array}$ & $\begin{array}{c}3.8 \pm 2.28 \\
3.34,0.5-14.5\end{array}$ & $\begin{array}{c}5.8 \pm 2.65^{c} \\
5.9,1.2-11.3\end{array}$ & $\begin{array}{c}4.26 \pm 2.7 \\
3.26,0.87-10.5\end{array}$ \\
\hline ACTH (pg/ml) & $\begin{array}{l}10.1 \pm 5.6^{\mathrm{a}} \\
9.8,2-28.6\end{array}$ & $\begin{array}{l}22.0 \pm 9.8 \\
20,2-55.5\end{array}$ & $\begin{array}{l}8.9 \pm 6.1^{b} \\
7.25,2-24\end{array}$ & $\begin{array}{c}20.6 \pm 8.3 \\
19.2,6.6-41\end{array}$ \\
\hline DHEA-S ( $\mu \mathrm{g} / \mathrm{dl})$ & $\begin{array}{c}47.3 \pm 32.8^{\mathrm{a}} \\
41.45,14-199\end{array}$ & $\begin{array}{c}91.2 \pm 61.0 \\
71.1,11.5-303\end{array}$ & $\begin{array}{c}52.7 \pm 24.5^{b} \\
47.5,13.7-115\end{array}$ & $\begin{array}{c}96.7 \pm 69.1 \\
77.0,26.5-344\end{array}$ \\
\hline UFC ( $\mu \mathrm{g} / \mathrm{dl})$ & $\begin{array}{c}62.7 \pm 30.7^{d} \\
57.7,15-156.2\end{array}$ & $\begin{array}{c}50.2 \pm 30.5 \\
43.4,13.3-167.6\end{array}$ & $\begin{array}{c}73.4 \pm 37.9 \\
66.9,25-173.5\end{array}$ & $\begin{array}{c}63.2 \pm 36.2 \\
53,15.6-183\end{array}$ \\
\hline
\end{tabular}

SCS, subclinical Cushing's syndrome; NF, normal adrenal function; WC, waist circumference; IGT, impaired glucose tolerance; LDDST, low-dose dexamethasone suppression test.

${ }^{a} P<0.001$ for UAI-SCS vs UAI-NF.

${ }^{\mathrm{b}} P<0.001$ for BAI-SCS vs BAI-NF.

${ }^{c} P<0.05$ for BAI-SCS vs BAI-NF.

d $P<0.05$ for UAI-SCS vs UAl-NF.

between patients with BAI and UAI was investigated in detail for the first time in a study in 2006, aiming to examine whether N363S and ER22/23K variants of the glucocorticoid receptor gene could be associated with the development of adrenal incidentalomas (13). Till then, in spite of the large number of studies of patients with adrenal incidentalomas, no specific and focused analysis of this subgroup of patients has been carried out. That study showed a significantly higher carrier frequency for the N363S variant and an increased frequency of type 2 diabetes in BAI patients compared with UAI patients, without any difference in hormonal abnormalities compatible with subtle cortisol hypersecretion, between the two groups (13). However, the frequency of SCS was not specifically addressed. Since 2006 , four studies $(15,16,17$, 18) have investigated the possibility of a different prevalence of SCS and potentially related morbidities between patients with BAI and UAI with controversial results (Table 4 ).
In our study, the prevalence of SCS was significantly higher in patients with BAI, and this was in agreement with the studies by Vassiliadi et al. (15) and Olsen et al. (17) and at variance with the studies by Androulakis et al. (16) and Morelli et al. (18) that detected no difference. This variation could be partly attributed to different biochemical criteria used for the diagnosis of SCS (as shown in Table 4), given that there is still no consensus for the optimal laboratory evaluation for its diagnosis.

In agreement with our previous work (10), patients with SCS had larger adrenal masses. This finding persisted when patients with UAI were analyzed separately from patients with BAI, as described previously $(17,18)$. In another study, the size of adrenal mass was positively related to hormonal abnormalities compatible with subtle cortisol hypersecretion (namely, positively related to serum post-LDDST cortisol levels and negatively related to ACTH and DHEA-S levels) in the whole cohort (15). We also found that the probability of SCS in the whole cohort of patients 
Table 4 Studies examining possible differences in subclinical Cushing's syndrome between patients with unilateral and bilateral adrenal incidentalomas.

\begin{tabular}{|c|c|c|c|c|c|c|c|c|}
\hline References & Patients $(n)$ & $\begin{array}{c}\text { Mass size }(\mathrm{cm}) \\
\text { UAI }\end{array}$ & $\begin{array}{c}\text { Mass size }(\mathrm{cm}) \\
\text { BAI }\end{array}$ & $P$ value & $\begin{array}{l}\text { Diagnostic criteria } \\
\text { for SCS }\end{array}$ & SCS-UAI & SCS-BAI & $P$ value \\
\hline (15) & 172 & $2.3 \pm 1.1$ & $3.8 \pm 1.2$ & $<0.001$ & $\begin{array}{l}\text { LDDST }>70 \mathrm{nmol} / \mathrm{I}^{\mathrm{a}} \\
\text { Fmidnight }> \\
250 \mathrm{nmol} / \mathrm{l} \\
\text { ACTH }<2.2 \mathrm{pmol} / \mathrm{l} \\
\mathrm{UFC}>331 \mathrm{nmol} / 24 \mathrm{~h}\end{array}$ & $\begin{array}{c}16 / 131 \\
(12.2 \%)\end{array}$ & $\begin{array}{c}17 / 41 \\
(41.5 \%)\end{array}$ & $<0.001$ \\
\hline (16) & 149 & $2.46 \pm 1.3$ & $\begin{array}{l}2.56 \pm 1.2(\mathrm{R}) \\
2.44 \pm 1.1(\mathrm{~L})\end{array}$ & NS & $\begin{array}{l}\text { LDDST } \geq 34.1 \mathrm{nmol} / \mathrm{l} \\
\text { (cut-off based on a } \\
\text { control population) }\end{array}$ & $\begin{array}{c}48 / 116 \\
(42.5 \%)\end{array}$ & $\begin{array}{c}15 / 36 \\
(41.7 \%)\end{array}$ & NS \\
\hline $\begin{array}{l}\text { Olsen et al. } \\
\text { (2012) (17) }\end{array}$ & 142 & $\begin{array}{c}2.0 \\
\text { (median) }\end{array}$ & $\begin{array}{c}2.4 \\
\text { (median) }\end{array}$ & NS & $\begin{array}{l}\text { ODST } \geq 50 \mathrm{nmol} / \mathrm{l} \\
\mathrm{ACTH}<2 \mathrm{pmol} / \mathrm{l}\end{array}$ & $\begin{array}{l}27 / 115 \\
(23 \%)\end{array}$ & $\begin{array}{c}13 / 31 \\
(42 \%)\end{array}$ & 0.04 \\
\hline (18) & 213 & $2.5 \pm 1.1$ & $4.2 \pm 1.6^{b}$ & 0.001 & $\begin{array}{l}\text { ODST }>83 \mathrm{nmol} / /^{\mathrm{c}} \\
\mathrm{ACTH}<2.2 \mathrm{pmol} / \mathrm{l} \\
\mathrm{UFC}>193 \mathrm{nmol} / 24 \mathrm{~h}\end{array}$ & $\begin{array}{l}41 / 175 \\
23.4 \%\end{array}$ & $\begin{array}{r}10 / 38 \\
26.3 \%\end{array}$ & NS \\
\hline Present study & 298 & $2.4 \pm 1.1$ & $2.6 \pm 1.0$ & NS & 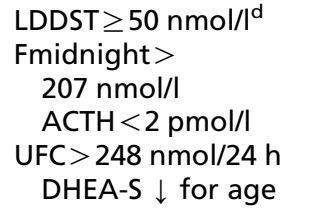 & $\begin{array}{l}40 / 224 \\
17.9 \%\end{array}$ & $\begin{array}{l}26 / 74 \\
35.1 \%\end{array}$ & 0.003 \\
\hline
\end{tabular}

UAl, patients with unilateral adrenal incidentalomas; BAI, patients with bilateral adrenal incidentalomas; SCS, subclinical Cushing's syndrome; R, right adrenal; L, left adrenal; LDDST, low-dose dexamethasone suppression test; UFC, urinary free cortisol; and ODST, overnight dexamethasone suppression test. ${ }^{a}$ LDDST combined with at least one out of three tests (Fmidnight, ACTH, and UFC levels).

${ }^{b}$ Mass size BAl: the sum of diameters of adrenal lesions.

'Combination of at least two out of three tests (ODST, ACTH, and UFC).

dLDDST combined with at least one out of four tests (Fmidnight, ACTH, UFC, and DHEA-S levels).

correlates positively with the adrenal mass size, in agreement with previous data (17). All these data support the importance of the size of the adrenal mass/masses when evaluating patients for the presence of subtle cortisol hypersecretion. We think that the fact that the adrenal mass size in patients with UAI was comparable with the size of the largest mass in those with bilateral incidentalomas in our study permitted a more precise assessment of the effect of adrenal mass bilaterality on subtle cortisol hypersecretion. This is based on the hypothesis that, in most cases with bilateral incidentalomas and subtle cortisol hypersecretion, one adrenal mass - the larger one - is hypersecreting. This hypothesis is supported by a catheterization study where unilateral cortisol hypersecretion was documented in five out of seven patients with bilateral incidentalomas and SCS, and in four out of these five patients, the larger adrenal mass was concerned (23).

Patients with typical imaging findings of ACTHindependent macronodular adrenal hyperplasia were excluded from the study, because this rare entity that causes Cushing's syndrome may occasionally present with subclinical cortisol hypersecretion (24). However, the possibility of ACTH-independent macronodular adrenal hyperplasia cannot be completely ruled out based on imaging findings, as histological diagnosis has been reported in patients with discrete adrenal lesions (23). It has to be noted that Morelli et al. (18) found no difference in the frequency of SCS between patients with BAI and UAI, in spite of the fact that the majority (30 out of 38) of patients with BAI had macronodular adrenal hyperplasia.

The prevalence in patients with BAI $(24.8 \%)$ in our study was similar to the one (17.8-24.2\%) reported in studies that have addressed this issue $(15,16,17,18)$, although higher than the reported $7.8-10.0 \%$ prevalence in large cohorts $(4,9)$, probably due to referral bias.

In our cohort of patients, the prevalence of SCS was significantly higher in patients with BAI, a finding possibly related to different pathophysiologies. This hypothesis is supported by the fact that BAI are encountered more often than expected from the coincidence of a single adenoma in both adrenals (13). However, there are very few data suggesting possible pathogenetic differences between UAI and BAI $(13,14)$, although the pathogenesis of sporadic adrenal tumors is under research, and molecular studies on genetic changes and gene expression alterations are advancing knowledge in this field (25).

In this study, the frequency of obesity and morbidities that could be considered as adverse effects of subtle cortisol hypersecretion (i.e. hypertension, type 2 diabetes, and dyslipidemia) did not differ between patients with BAI 
and UAI, and this was in agreement with the findings of Morelli et al (18). At variance, Vassiliadi et al. (15) reported an increased frequency of hypertension in patients with UAI. Our findings together with the detected increased prevalence of SCS in patients with BAI indicate that the different prevalence of subtle cortisol hypersecretion is not leading to a different frequency of possible clinical implications. This is not surprising as clinical manifestations of cortisol hypersecretion are variable depending on the degree and duration of cortisol hypersecretion and interindividual sensitivity to the cortisol excess (26). Cortisol secretion in patients with adrenal incidentalomas presents a wide range of variability from normal secretion to autonomous cortisol hypersecretion, and intermittent subclinical autonomous cortisol hypersecretion has also been shown in some patients during follow-up $(10,27$, 28). In this setting, it can be explained why no clear-cut difference in the frequency of potentially related morbidities to subtle cortisol hypersecretion has been shown between clinically silent adrenal incidentaloma patients with and without SCS $(6,11)$. In addition, patients with intermittent cortisol secretion may present with adverse effects; however, they can have normal adrenal function at a single evaluation. This is a plausible explanation for the improvement in arterial hypertension, type 2 diabetes, and insulin sensitivity after adrenalectomy, reported in adrenal incidentaloma patients with $(7,8,29,30,31,32)$ and without SCS $(8,31,32)$. This might also be the case for transient adrenal insufficiency after adrenalectomy, considered as an indirect proof of cortisol hypersecretion, described in patients with and without $\operatorname{SCS}(8,32)$. It should also be noted that morbidities considered as adverse effects of subtle cortisol hypersecretion are not specific for cortisol excess and have an increased prevalence in the general population, especially over the sixth decade of life, when adrenal incidentalomas are more frequently detected.

A limitation of this study is its cross-sectional design. Follow-up data would permit a better assessment of subtle cortisol hypersecretion in relation to the presence of bilateral adrenal adenomas. Another limitation of this study is the change of assays for ACTH and DHEA-S measurements during the 11-year-period of the study, contributing to the variability of results.

In conclusion, our data show that SCS is more prevalent in BAI patients when compared with UAI patients, although morbidities potentially related to this disorder are of a similar frequency in the two groups of patients. Further studies are needed to clarify whether this difference in hormonal activity may be related to different pathophysiologies.

\section{Declaration of interest}

The authors declare that there is no conflict of interest that could be perceived as prejudicing the impartiality of the research reported.

\section{Funding}

This research did not receive any specific grant from any funding agency in the public, commercial or not-for-profit sector.

\section{References}

1 Kloos RT, Gross MD, Francis IR, Korobkin M \& Shapiro B. Incidentally discovered adrenal masses. Endocrine Reviews 199516 460-484.

2 Herrera MF, Grant CS, van Heerden JA, Sheedy PF \& Ilstrup DM. Incidentally discovered adrenal tumors: an institutional perspective. Surgery 1991110 1014-1021.

3 Bovio S, Cataldi A, Reimondo G, Sperone P, Novello S, Berruti A, Borasio P, Fava C, Dogliotti L, Scagliotti GV et al. Prevalence of adrenal incidentaloma in a contemporary computerized tomography series. Journal of Endocrinological Investigation 200629 298-302. (doi:10.1007/ BF03344099)

4 Song JH, Chaudhry FS \& Mayo-Smith WW. The incidental adrenal mass on CT: prevalence of adrenal disease in 1,029 consecutive adrenal masses in patients with no known malignancy. AJR. American Journal of Roentgenology 2008190 1163-1168. (doi:10.2214/AJR.07.2799)

5 Barzon L, Sonino N, Fallo F, Palu G \& Boscaro M. Prevalence and natural history of adrenal incidentalomas. European Journal of Endocrinology 2002146 61-66. (doi:10.1530/eje.0.1460061)

6 Terzolo M, Bovio S, Reimondo G, Pia A, Osella G, Borretta G \& Angeli A. Subclinical Cushing's syndrome in adrenal incidentalomas. Endocrinology and Metabolism Clinics of North America 200534 423-439. (doi:10.1016/j.ecl.2005.01.008)

7 Reincke M, Nieke J, Krestin GP, Saeger W, Allolio B \& Winkelmann W. Preclinical Cushing's syndrome in "adrenal incidentalomas": comparison with adrenal Cushing's syndrome. Journal of Clinical Endocrinology and Metabolism 199275 826-832.

8 Rossi R, Tauchmanova L, Luciano A, Di Martino M, Battista C, Del Viscovo L, Nuzzo V \& Lombardi G. Subclinical Cushing's syndrome in patients with adrenal incidentaloma: clinical and biochemical features. Journal of Clinical Endocrinology and Metabolism 200085 1440-1448.

9 Mantero F, Terzolo M, Arnaldi G, Osella G, Masini AM, Ali A, Giovagnetti M, Opocher G \& Angeli A. A survey on adrenal incidentaloma in Italy. Study group on adrenal tumors of the Italian Society of Endocrinology. Journal of Clinical Endocrinology and Metabolism 200085 637-644.

10 Vassilatou E, Vryonidou A, Michalopoulou S, Manolis J, Caratzas J, Phenekos C \& Tzavara I. Hormonal activity of adrenal incidentalomas results from a long term follow-up study. Clinical Endocrinology $2009 \mathbf{7 0}$ 674-679. (doi:10.1111/j.1365-2265.2008.03492.x)

11 Arnaldi G \& Boscaro M. Adrenal incidentaloma. Best Practice and Research. Clinical Endocrinology and Metabolism 201226 405-419. (doi:10.1016/j.beem.2011.12.006)

12 Zeiger MA, Siegelman SS \& Hamrahian AH. Medical and surgical evaluation and treatment of adrenal incidentalomas. Journal of Clinical Endocrinology and Metabolism 201196 2004-2015. (doi:10.1210/jc. 2011-0085 
13 Majnik J, Patocs A, Balogh K, Toth M, Gergics P, Szappanos A, Mondok A, Borgulya G, Panczel P, Prohaszka Z et al. Overpresentation of the N363S variant of the glucocrticoid receptor gene in patients with bilateral adrenal incidentalomas. Journal of Clinical Endocrinology and Metabolism 200691 2796-2799. (doi:10.1210/jc.2006-0066)

14 Patocs A, Toth M, Barta C, Sasvari-Szekely M, Varga I, Szucs N, Jakab C, Glaz E \& Racz K. Hormonal evaluation and mutation screening for steroid 21-hydroxylase deficiency in patients with unilateral and bilateral adrenal incidentalomas. European Journal of Endocrinology 2002 147 349-355. (doi:10.1530/eje.0.1470349)

15 Vassiliadi DA, Ntali G, Vicha E \& Tsagarakis S. High prevalence of subclinical hypercortisolism in patients with bilateral adrenal incidentalomas: a challenge to management. Clinical Endocrinology $2011 \mathbf{7 4}$ 438-444. (doi:10.1111/j.1365-2265.2010.03963.x)

16 Androulakis I, Kaltsas G, Markou A, Tseniklidi E, Kafritsa P, Pappa T, Papanastasiou L \& Piaditis G. The functional status of incidentally discovered bilateral adrenal lesions. Clinical Endocrinology 201175 44-49. (doi:10.1111/j.1365-2265.2011.04013.x)

17 Olsen H, Nordensrom E, Bergenfelz A, Nyman U, Valdemarsson S \& Palmqvist E. Subclinical hypercortisolism and CT appearance in adrenal incidentalomas: a multicenter study from Southern Sweden. Endocrine 201242 164-173. (doi:10.1007/s12020-012-9622-2)

18 Morelli V, Palmieri S, Salcuni AS, Eller-Vainicher C, Cairoli E, Zhukouskaya V, Scillitani A, Beck-Peccoz P \& Chiodini I. Bilateral and unilateral adrenal incidentalomas: biochemical and clinical characteristics. European Journal of Endocrinology 2013168 235-241. (doi:10.1530/EJE-12-0777)

19 Clinical guidelines on the identification, evaluation and treatment of overweight and obesity in adults - the evidence report. National Institutes of Health. Obesity Research 19986 (Suppl 2): 51S-209S

20 JNC VI. The sixth report of the Joint National Committee on prevention, detection, evaluation, and treatment of high blood pressure. Archives of Internal Medicine 1997157 2413-2446. (doi:10.1001/archinte.1997.00440420033005)

21 The Expert Committee on the Diagnosis and Classification of Diabetes Mellitus. Diabetes Care 199720 1183-1197.

22 National Cholesterol Educational Programm (NCEP) Expert Panel on detection, evaluation and treatment of high blood cholesterol in adults (Adult Treatment Panel III). Third report of the National Cholesterol Educational Programm (NCEP) Expert Panel on detection, evaluation and treatment of high blood cholesterol in adults (Adult Treatment Panel III) Final Report. Circulation 20021063143.

23 Young WF Jr, du Plessis H, Thompson GB, Grant CS, Farley DR, Richards ML, Erickson D, Vella A, Stanson AW, Carney JA et al.
The clinical conundrum of corticotropin-independent autonomous cortisol secretion in patients with bilateral adrenal masses. World Journal of Surgery 200832 856-862. (doi:10.1007/s00268-007-9332-8)

24 Bourdeau I, D'Amour P, Hamet P, Boutin JM \& Lacroix A. Aberrant membrane hormone receptors in incidentally discovered bilateral macronodular adrenal hyperplasia with subclinical Cushing's syndrome. Journal of Clinical Endocrinology and Metabolism 200186 5534-5540.

25 Roussel HW, Vezzosi D, Rizk-Rabin M, Barreau O, Ragazzon B, RenéCorail F, Reynies A, Bertherat J \& Assie G. Identification of gene expression profiles associated with cortisol secretion in adrenocortical adenomas. Journal of Clinical Endocrinology and Metabolism 201398 E1109-E1121. (doi:10.1210/jc.2012-4237)

26 Nieman LK, Biller BM, Findling JW, Newell-Price J, Savage MO, Stewart PM, Victor M \& Montori VM. The diagnosis of Cushing's syndrome: an Endocrine Society Clinical Practice Guideline. Journal of Clinical Endocrinology and Metabolism 200893 1526-1540. (doi:10.1210/ jc.2008-0125)

27 Terzolo M, Osella G, Ali A, Borretta G, Cesario F, Paccotti P \& Angeli A. Subclinical Cushing's syndrome in adrenal incidentaloma. Clinical Endocrinology 199848 89-97. (doi:10.1046/j.1365-2265.1998.00357.x)

28 Bernini GP, Moretti A, Oriandini C, Bardini M, Taurino C \& Salvetti A. Long-term morphological and hormonal follow-up in a single unit on 115 patients with adrenal incidentalomas. British Journal of Cancer 2005 92 1104-1109. (doi:10.1038/sj.bjc.6602459)

29 Toniato A, Merante-Boschin I, Opocher G, Pelizzo MR, Schiavi F \& Ballotta E. Surgical versus conservative management for subclinical Cushing syndrome in adrenal incidentalomas: a prospective randomized study. Annals of Surgery 2009249 388-391. (doi:10.1097/SLA. 0b013e31819a47d2)

30 Perysinakis I, Marakaki C, Avlonitis S, Katseli A, Vassilatou E, Papanastasiou L, Piaditis G \& Zografos GN. Laparoscopic adrenalectomy in patients with subclinical Cushing syndrome. Surgical Endoscopy 201327 2145-2148. (doi:10.1007/s00464-012-2730-5)

31 Bernini G, Moretti A, Iacconi P, Miccoli P, Nami R, Lucani B \& Salvetti A. Anthropometric, haemodynamic, humoral and hormonal evaluation in patients with incidental adrenocortical adenomas before and after surgery. European Journal of Endocrinology 2003148 213-219. (doi:10.1530/eje.0.1480213)

32 Chiodini I, Morelli V, Stefano Salcuni A, Eller-Vainicher C, Torlontano M, Coletti F, Lorio L, Cuttitta A, Ambrosio A, Vicentini L et al. Beneficial metabolic effects of prompt surgical treatment in patients with an adrenal incidentaloma causing biochemical hypercortisolism. Journal of Clinical Endocrinology and Metabolism 201095 2736-2745. (doi:10.1210/jc.2009-2387)

Received 17 October 2013

Revised version received 13 April 2014

Accepted 15 April 2014 